\title{
Coordination, cooperation and collaboration in logistics and supply chains: a bibliometric analysis
}

\author{
Herbert Kotzab $^{\mathrm{a}, \mathrm{b} *}$ (D), Inga-Lena Darkow ${ }^{\mathrm{c}}$ (D), llja Bäumler ${ }^{\mathrm{a}}$ (D), Christoph Georgid \\ aUniversität Bremen, Bremen, Germany

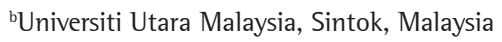 \\ 'Ningbo Supply Chain Innovation Institute China, Zhejiang, China \\ ${ }^{d}$ EBS Universität für Wirtschaft und Recht gGmbH, Wiesbaden, Hessen, Germany \\ *kotzab@uni-bremen.de
}

\begin{abstract}
Paper aims: This paper identifies, evaluates and structures the research that focuses on supply chain coordination, cooperation and collaboration (CCC) within the domain of production economics and reveals its intellectual foundation.

Originality: The paper develops a distinct CCC-model, which enables a clear distinction between the elements of CCC based on five criteria. Afterwards, it presents the most influential papers and authors when it comes to CCC in supply chain production economics research. It also provides a visualised intellectual structure of five citation subfields and their interrelations.
\end{abstract}

Research method: Based on the reference list of more than 270 CCC-related papers, the authors perform a citation and co-citation analysis of the 47 most frequently cited papers in one selected academic journal. This analysis included multidimensional scaling, factor analysis as well as cluster analysis.

Main findings: The study reveals the intellectual base of CCC in a production economic-specific research domain, which reflects coordination only. The citation clusters represent different aspects of supply chain coordination mechanisms such as contractual agreements, information sharing and buyer-vendor integration. One subfield represents methodological aspects.

Implications for theory and practice: Neither cooperation nor collaboration related sources were identified in the most frequently used papers which certainly offers a research gap that needs to be closed in the future.

Keywords

Supply chain management. Foundation. Citation analysis. Co-citation analysis.

How to cite this article: Kotzab, H., Darkow, 1. L., Bäumler, 1., \& Georgi, C. (2019). Coordination, cooperation and collaboration in logistics and supply chains: a bibliometric analysis. Production, 29, e20180088. https://doi.org/10.1590/01036513.20180088

Received: Sept. 27, 2018; Accepted: June 28, 2019.

\section{Introduction}

\subsection{Starting points of considerations}

Supply chains can be defined as long, complex and interwoven sequences of order-connected firms (see Kotzab \& Otto, 2004). The management of such chains is concerned with the identification of an optimal strategy for the complete chain which induces an integration of business processes amongst a number of companies (Ryu et al., 2013). This integration is based on different levels of interaction of the involved firms ranging from harmonizing or synchronising activities (= coordination) to working together as equal partners (= cooperation) and even acting as one single entity (= collaboration). 
By this, the inter-firm related trade-off between inventory and information (sharing) can be addressed as it requires more close than adversarial relationships between e.g. a supplier and a buyer (see e.g. Ellram \&t Cooper, 1990; LaLonde \& Masters, 1990). Consequently, it is no surprise that the constructs of 'coordination', 'cooperation' and 'collaboration' (CCC) gained also a lot of attention and importance for production research. Frankel et al. (2008) or Mentzer et al. (2008) argue here that coordination and integration are essential 'ingredients' in order to harmonize operations among members in a supply chain.

While researchers have examined specific results and/or effects of supply chain coordination, cooperation and/or collaboration (see e.g. Cao et al., 2010; Ding et al., 2011; Kaur et al., 2008), we are more interested in the intellectual foundation of these important constructs for Supply Chain Management (SCM) research or differently expressed: where does supply chain related CCC research taking its ideas from? The term 'intellectual foundation' refers to those papers, monographs or other contributions to a discipline's knowledge which significantly impacted subsequent research and related methodology. In studying the intellectual foundation of SCM-related CCC research, the most influential research publications will be identified, their interrelationships displayed, and the emergence and dominance of thematic trends in publications will be revealed, which includes also extra-disciplinary works which researchers regularly draw upon (e.g. White \&t McCain, 1998).

\subsection{Research objectives}

The overall purpose of the paper is to identify the most important papers and authors and their interrelations in regards to CCC by the means of bibliometric analysis including citation and co-citation analysis. According to Zupic \& Č Čter $(2015$, p. 430) bibliometric studies differ from literature reviews by its "[...] quantitative approach for the description, evaluation, and monitoring of published research", which means they examine the literature which is used to write a paper (see e.g. Assad \& Golden, 1982; Banker \& Kauffman, 2004; Hopp, 2004). As such bibliometric studies are seen as a very useful step before starting a literature review as they map a research field without a subjective bias (see Zupic \& Čater, 2015). Indeed, the outcome of bibliometric studies represent the attention of a scientific field by a community through citations and can thereby identify research networks (e.g. Garfield, 1979; or Baier-Fuentes et al., 2019). As such, bibliometric studies can provide increased objectivity in literature reviews (Zupic \&t Čater, 2015).

In our case we focused our research attention to one specific research domain/journal, which is the International Journal of Production Economics (IJPE). The journal is a well-accepted outlet for research within the Production and Operations Management community as Darkow et al. (2010) have shown in their citation analysis of the leading 50 SCM and logistics related academic journals. The $57^{\text {th }}$ edition of the Harzing (2016) list indicates IJPE as a 3 star journal in the ABS 2015 list as well as a B-journal of VHB jourqual. The editorial statement says that it combines "[...] the high standards of a traditional academic approach with the practical value of industrial applications" (Grubbström, 2016, p. 1) so that rigor and relevance are highly considered. By selecting one particular research outlet we are getting a clear picture on how one specific research community discusses CCC without diluting the result by being exposed to too diverse journal settings.

As we are going to show in our methodological section, IJPE showed the highest number of hits when it came to our literature search. Taking all these considerations into account, we selected IJPE as our research object in order to detect the intellectual bases on CCC.

We response these objectives by applying an empirical study based on bibliometric analysis, in particular citation and co-citation analysis. While citations are used to estimate the influence of documents/authors/journals by using citation rates, co-citation connects documents/authors/journals on the ground of joint presence in the list of references (see e.g. Zupic \& Čater, 2015). Thus, this approach is understood as a specific method to study an academic field, its development and utilization of knowledge (see e.g. Garfield, 1979; Georgi et al., 2010; Hoffman \& Holbrook, 1993; Smith, 1981; for an insight into bibliometric analysis in the field of logistics/SCM see Georgi et al., 2013).

Consequently, the results of our paper offer a starting point for researchers, graduate students, faculty members or practitioners who wish to explore CCC research in the context of SCM. Our paper identifies common citation themes and highlights fundamental studies in order to provide an overview of research themes that are already investigated. This article is also meant to motivate and inspire individuals for this exciting area of research, which has become a vital topic in today's competitive environment.

While this paper provides a comprehensive account of peer-reviewed articles, it also offers valuable insight to practitioners and allows them to judge whether or not current research draws on appropriate conceptual and methodological literature to advance the knowledge in the respective research area, as well as in the field 
at large. Similarly, the identification of the most influential publications and their affiliation with subject areas may support educators and new researchers in selecting appropriate literature according to their interests.

The remainder of the paper is organized as follows: After having presented our problem background and statement we define the construct of CCC. Subsequently, we provide the methodological background on the techniques employed in this paper. Afterwards we present and discuss the results of our study. Finally, we summarize the conclusions to be drawn from our investigation and indicate limitations and further research opportunities.

\section{Defining the construct of $\mathrm{CCC}$}

When checking SCM literature, we recognise that the terms 'coordination', 'cooperation' and 'collaboration' are not used in a clear and indisputable way in this particular context. These constructs are rather used to describe more or less the same type or level of inter-firm arrangements.

The introduction of SCM in the late 1980's (see Houlihan, 1985; Jones \&t Riley, 1985; Stevens, 1989) changed the organisational mindset of logistics as the design of all flows of goods and related information is no longer an internal issue but refers to all stages between an initial supplier until an ultimate customer (see Mentzer et al., 2001). This boundary-spanning identity of SCM requires not only higher emphasis on integration and optimisation efforts across companies but also a more long-term oriented attitude in activities with related partners as compared to traditional logistics thinking (see e.g. Kotzab \&t Biedermann, 2018).

In order to realise the benefits of SCM, Fugate et al. (2006) identify the creation of synergistic relationships amongst all supply chain partners as a necessity for being able to maximise customer value and providing a fair share of supply chain profitability for the members in a supply chain. They hereby refer to supply chain coordination as a mean to align the actions of the individual supply chain members with the overall supply chain objectives. Contrary to this, Horvath (2001) defines collaboration as the key to successful SCM but refers to different levels of collaboration (from low-cost connectivity to supply chain collaboration exchanges). Barratt (2004), in turn defines such closer inter-organisational interaction as expression of collaboration, which can be realised on different levels (horizontally as well as vertically) within the firm and between firms and their suppliers, customers and/or even competitors.

Furthermore, we find Bowersox (1990, p. 36-43) who argues that supply chain collaboration simplifies the cooperation of supply chain members while Monczka et al. (2009, p. 122) understand supply collaboration as a process between two or more supply chain participants who build a high degree of cooperative behaviour with the goal of a long trade relationship. Recently, Burke et al. (2012) understands supply chain collaboration as an important driver for supply chain strategy which has a positive influence on the operational and relational outcomes which affect firm performance positively. Interestingly, Albino et al. (2007) confirm these notions but call this cooperation amongst supply chain partners who decide to pursue a common goal to improve their performance. The authors use therefore the term 'collaborate' while Cachon (2003) speaks here of the coordination of supply chain actors and how the actions in this endeavour can be contractually secured.

These few examples already show that the supply chain management research community uses the terms in an ambiguous manner and that there is a need for a clear distinction between coordination, cooperation and collaboration.

In this paper, we follow the notions of Kaur et al. (2008) and understand (supply chain) coordination as a goal-oriented process of harmonising interdependent activities of supply chain partners. We further use El Omri's definition of (supply chain) cooperation which is given, when supply chain partners start to work together in order to achieve common goals (El Omri, 2009). Finally, whenever supply chain actors start to share responsibility of exchanging common supply chain management measures which makes them appear as one single entity and allow them to achieve higher profitability as compared to as acting alone, we define this as collaboration (Cao et al., 2010; Min et al., 2005).

Even though the terms may be used interchangeably (Kaur et al., 2011), there is a certain difference between the individual parts of CCC which mainly refers to the degree of liaising with actors in a supply chain. According to Göpfert (2016, p. 80-81) cooperation is thus defined as the purpose to achieve the best possible goal objectives between individual organizations and suborganizations. Coordination though describes the harmonisation of business processes, which must be mutually adjusted in order to achieve goal objectives efficiently (Göpfert, 2016). Taking all these into account we further understand CCC as an expression of different levels of supply chain partnerships which Son (2004) evaluates on following five intensity levels:

1. (Level of) information exchange: This allows the connection between IT and business relationships. Moreover, adequate $\mathrm{IT}$ and the willingness to exchange information reduce the costs of the relationship and increases the 
capacity of inter-firm communication. By intensifying the quantity and quality of the information exchange as well as its timeliness, the level of a supply chain partnership towards the achievement of common goals can be increased (see Clemons \& Row, 1992);

2. (Level of) trust: This important element of any supply chain partnership reduces uncertainty and the dangers of opportunism into disadvantageous relationships (Fawcett et al., 2004; Maloni \& Benton, 2000; or Son, 2004). A high level of trust enables an effective compensation and risk-sharing system for supply chain partners (Bowersox, 1990; Ellram \& Cooper, 1990), which many companies see as a reason for working with other companies;

3. (Level of) joint partnership management system: This element is required for developing, maintaining and monitoring supply chain relationships (Stuart, 1997). Additionally, it consists of a joint decision-making system and a reward and risk sharing system (Son, 2004). If well-structured, such systems increase the frequency of contact and consequently positively affect the partnership performance (Heide \& Miner, 1992);

4. (Level of) relationship specific asset: These refer to any specific investments particularly and uniquely tailored for a partnership. Relationship specific assets also have a low value outside a partnership (Son, 2004). They can be physical, location-based, human, or intangible (e.g. software) (Kim \& Umanath, 2005). Relationship specific assets are an important way to increase the collaboration of two or more supply chain partners (Son, 2004);

5. (Level of) partner asymmetry: This refers either to differences in the reciprocal strengths which partners provide or to differences in partner characteristic. While the first affects the relationship positively the second has a negative influence on the supply chain partnership (Parkhe, 1991; Son, 2004).

In Figure 1 we confront CCC with Son's (2004) notions and position the individual constructs into this framework.

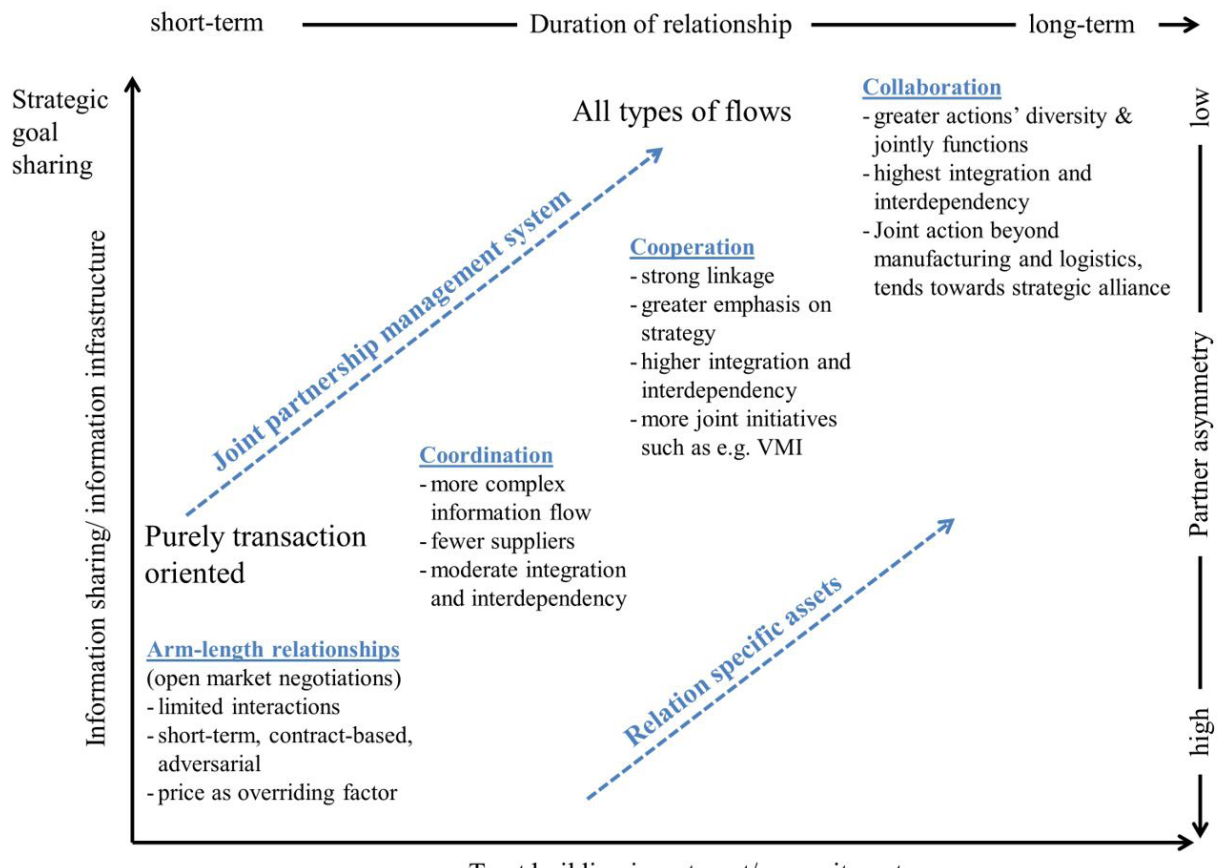

Trust building investment/ commitment

Figure 1. CCC-model between firms (see Son, 2004).

Taking all this into account, it is becoming obvious that the interchangeable use of 'coordination', 'cooperation' and 'collaboration' in a supply chain context cannot be supported, as the degree of the supply chain partnership intensity drives the level of exchange activity between supply chain members.

After this theoretical clarification, we are interested to distinguish the fundamentals of CCC within production economic related research. 


\section{Methodological considerations}

\subsection{Data collection}

In a first step, we collected articles published in peer-reviewed academic journals which dealt with CCC. This phase is the most crucial one as this set of articles define the scholarly landscape being mapped. In order to generate our data set we performed in a first stage a literature search in EBSCO's Business Source Complete (BSC), one of the world's largest electronic databases covering nearly 2,000 peer-reviewed academic journals (EBSCO, 2016). Our search included all academic (peer-reviewed) articles published between 1998 and 2013 which contained the search terms 'supply chain', 'logistics', 'operations', 'collaboration', 'coordination' and/or 'collaboration' in any of the title (TI), abstract (AB), or author-supplied keyword (KW) fields. This search yielded in more than 2,700 hits out of which 1,518 were published in 50 peer-reviewed academic journals out of which IJPE $(n=172)$, EJOR $(n=125)$ and IJPR $(=110)$ took the first three ranks, while the remaining 47 showed less than 100 hits.

Following the notions of Georgi et al. (2010), Lindquist \& Smith (2009), Ramos-Rodríguez \& Ruíz-Navarro (2004) or Smith (2009), we continued with our work by focusing on IJPE as this journal had by far the most hits in our search.

After having discussed our search strategies with other peer researchers, we revised our search strategy by adapting our search terms for cooperation, coordination and collaboration to "collabo*', 'coordi*' and 'cooper*' as we were then able to identify our constructs not only in noun form but also as verbal expressions or as adjectives. Consequently, our sample extended to 278 articles that dealt more or less with cooperation, collaboration and/or coordination in a supply chain, logistics or operations setting. The identified number of articles represents about 7 per cent of all published articles in 1JPE within this period of time.

Based on these articles, our sampling process started by obtaining the bibliographic information of all cited documents as provided in BSC's 'cited references' feature that lists all documents referred to in the reference section of an article. In case this information was not available we were obtaining this information manually. Furthermore, we ignored the year of publication for book citations, which ensured that references made to books with multiple editions were not discriminated. Moreover, we ensured that multiple citations to a single document in one citing document were not counted, since reference sections (and thus BSC's 'cited references' feature) usually list a cited document only once. Thereafter we examined all citations for duplicates and for spelling mistakes of authors' names as well as spelling mistakes in the papers' titles. After this editing process, a total of 7,585 works that represent 10,381 citations were imported in our database for the citation study.

\subsection{Research design}

We performed our analysis in two steps. In the first step, we computed the citation frequencies of all documents and journals cited in the 278 sampled articles, followed by a co-citation analysis based on the most-cited documents and journals in the second step. The first step was necessary to identify the intellectual base (research questions 1), while the second step was performed in order to reveal the structure of the intellectual base (research question 2). We were able to identify distinct streams of literature and groups of journals (specialties) that have had a high impact on CCC research in IJPE.

In order to recognize the most influential work we needed to decide upon the minimum number of citations that a document needed to get so that it will be included in our analysis. This required also an examination of a sample size that would allow a fair representation of the documents. In line with Georgi et al. (2010) or Ramos-Rodríguez \&t Ruíz-Navarro (2004), we analysed our citation database by means of Kruskal's stress, which is used as an indicator of the goodness of fit of a multidimensional scaled (MDS) representation of data (Hair et al., 2014; Kruskal, 1964a, b).

We obtained a Kruskal's stress value of 0.10 which can be considered to be a sufficient to good fit (see Kruskal, 1964b) and chose for our further analysis to include a publication if it has been cited at least 10 times (= citation threshold) which reduced our database from 7,585 works to 47 works that were cited 780 times. Any other number would affect the clarity of the representation and the goodness of fit. We also included Moorthy (1987) with a citation frequency of seven as this work comments on Jeuland \& Shugan (1983) which is the eleventh most cited paper For these 47 papers we developed a co-citation matrix by using a self-developed computer script. 


\subsection{Data analysis}

We performed the co-citation analysis in accordance with Eom (2008), McCain (1990), White \&t Griffith (1981) or White \& McCain (1998). We applied for our MDS analysis the PROXSCAL routine and used Pearson's $r$ to measure the similarity between each pair of citations as this "[...] registers the likeliness in shape of their co-citations count profiles over all other [documents] in the set" (White \&t McCain, 1998, p. 331).

Besides that, the correlation matrices were analysed by using cluster analysis and factor analysis for supporting the interpretation of the results of the MDS (see Georgi et al., 2010, 2013). We used the hierarchical agglomerative clustering procedure with the complete-linkage algorithm and, for the factor analysis, we performed a principal component analysis with varimax rotation and Kaiser Normalization, extracting all factors with an Eigenvalue larger than one (see Hair et al., 2014).

Each involved researcher interpreted the results qualitatively and the individual results were afterwards discussed in order to reach a consensus on the interpretation results (Hill et al., 1997).

In the following section, only the MDS map indicating the identified subject groups is presented. Where the results of the three methods have not been fairly consistent, we indicate the respective divergence. The results of the cluster and factor analyses can be found in the Appendix A and B.

\section{Results}

\subsection{Overview}

We describe and discuss in this section the results of our citation and co-citation analysis based on 10,381 citations made in 278 articles, which are dealing with CCC and were published in IJPE between 1998 and 2013.

In a first step we present the intellectual foundation on CCC based on the 47 most cited works as presented in our Table 1 which shows that 39 publications are published in highly ranked academic journals while the remaining eight publications are well accepted monographs. Furthermore, we can observe a focus on mathematical programming which links this type of supply chain research with the field of operations research. Most of the used papers were published in rather OR-related journals (e.g. MS or EJOR). We also observe a kind of dominance of coordination-related and/or contract-related contributions. Additionally, we can see a focus on pricing/discounting issues from the perspective of channel profits and inventory management.

Table 1. The 47 most-cited publications on CCC research, 1998-2013.

\begin{tabular}{|c|c|c|c|}
\hline Cited publication & Year & $\mathrm{C}_{\mathrm{A}}$ & $C_{R}$ \\
\hline Cachon, G.P. & 2003 & 47 & 16.9 \\
\hline Cachon, G.P., Lariviere, M.A. [2] & 2005 & 36 & 12.9 \\
\hline Banerjee, A. & 1986 & 29 & 10.4 \\
\hline Weng, Z.K. & 1995 & 28 & 10.1 \\
\hline Giannoccaro, 1., Pontrandolfo, P. & 2004 & 28 & 10.1 \\
\hline Pasternack, B.A. & 1985 & 24 & 8.6 \\
\hline Tsay, A. & 1999 & 23 & 8.3 \\
\hline Tsay, A. Nahmias, S., Agrawal, N. & 1999 & 22 & 7.9 \\
\hline $\mathrm{Lu}, \mathrm{L}$ & 1995 & 20 & 7.2 \\
\hline Goyal, S.K. [3] & 1977 & 20 & 7.2 \\
\hline Jeuland, A.P., Shugan, S.M. & 1983 & 20 & 7.2 \\
\hline Monahan, J.P. & 1984 & 19 & 6.8 \\
\hline Chen, F., Federgruen, A., Zheng, Y.S. & 2001 & 19 & 6.8 \\
\hline Kaur, A., Kanda, A., Deshmukh, S.G. & 2008 & 19 & 6.8 \\
\hline Emmons, H., Gilbert, S.M. & 1998 & 19 & 6.8 \\
\hline Thomas, D.J., Griffin, P.M. & 1996 & 18 & 6.5 \\
\hline Lee, H.L., Rosenblatt, M.J. & 1986 & 17 & 6.1 \\
\hline Hair Jr., J.F., Black, W.C., Babin, B., Anderson, R., Tatham, R. & 1998 & 17 & 6.1 \\
\hline Hill, R.M. [1] & 1997 & 17 & 6.1 \\
\hline Lee, H.L., So, K.C., Tang, C.S. & 2000 & 17 & 6.1 \\
\hline
\end{tabular}

$\mathrm{C}_{\mathrm{A}}=$ absolute number of citations received; $\mathrm{C}_{\mathrm{R}}=$ relative number of citations received based on 278 'mother' articles; numbers in brackets indicate position of the work in MDS (see Figure 2). 
Table 1. Continued...

\begin{tabular}{|c|c|c|c|}
\hline Cited publication & Year & $\mathrm{C}_{\mathrm{A}}$ & $C_{R}$ \\
\hline Goyal, S.K. [1] & 1988 & 16 & 5.8 \\
\hline Goyal, S.K. [2] & 1995 & 16 & 5.8 \\
\hline Goyal, S.K., Gupta, Y.P. & 1989 & 16 & 5.8 \\
\hline Lariviere, M.A. & 1999 & 15 & 5.4 \\
\hline Lee, H.L., Padmanabhan, V., Whang, S. [1] & 1997 & 14 & 5.0 \\
\hline Nunnally, J.C., Bernstein, 1.H., Berge, J.M.F. & 1978 & 14 & 5.0 \\
\hline Li, J., Liu, L. & 2006 & 14 & 5.0 \\
\hline Frohlich, M.T., Westbrook, R. & 2001 & 13 & 4.7 \\
\hline Viswanathan, S., Piplani, R. & 2001 & 13 & 4.7 \\
\hline Silver, E., Pyke, D., Peterson, R. & 1998 & 13 & 4.7 \\
\hline Hill, R.M. [2] & 1999 & 13 & 4.7 \\
\hline Eppen, G.D., lyer, A.V. & 1997 & 12 & 4.3 \\
\hline Forrester, J.W. & 1961 & 12 & 4.3 \\
\hline Lee, H.L., Padmanabhan, V., Whang, S. [2] & 1997 & 12 & 4.3 \\
\hline Spengler, J. & 1950 & 12 & 4.3 \\
\hline Cachon, G.P., Lariviere, M.A. [1] & 2001 & 11 & 4.0 \\
\hline Munson, C.L, Rosenblatt, M.J. & 2001 & 11 & 4.0 \\
\hline Lee, H.L., Whang, S. & 1999 & 11 & 4.0 \\
\hline Çetinkaya, S., Lee, C.Y. & 2000 & 11 & 4.0 \\
\hline Taylor, T.A. & 2002 & 11 & 4.0 \\
\hline Cachon, G.P., Fisher, M. & 2000 & 11 & 4.0 \\
\hline Williamson, 0. & 1985 & 11 & 4.0 \\
\hline Lal, R., Staelin, R. & 1984 & 10 & 3.6 \\
\hline Donohue, K.L. & 2000 & 10 & 3.6 \\
\hline Lariviere, M.A., Porteus, E.L. & 2001 & 10 & 3.6 \\
\hline Chopra, S., Meindl, P. & 2001 & 10 & 3.6 \\
\hline Moorthy, K.S. & 1987 & 7 & 2.5 \\
\hline
\end{tabular}

$C_{A}=$ absolute number of citations received; $C_{R}=$ relative number of citations received based on 278 'mother' articles; numbers in brackets indicate position of the work in MDS (see Figure 2).

Table 2 looks at the journals and shows that 16 of the 39 journal articles stem from MS. The remaining 21 articles were published in journals related to operations management (e.g. 1JPE or DS) and operations research (EJOR) or marketing (MKTSCl) (see Table 2).

We consider the identified monographs as standard texts in the areas of contract theory (Tsay et al., 1999), multivariate data analysis (Hair et al., 1998), scale development (Nunnally \& Bernstein, 1978), supply chain management (Chopra \&t Meindl, 2001), new institutional economics (Williamson, 1985) and industrial dynamics (Forrester, 1961).

Table 2. The most cited journals in research on CCC in IJPE.

\begin{tabular}{lccc}
\hline \multicolumn{1}{c}{ Journal title } & Abbreviation & $\mathrm{C}_{\mathrm{A}}$ & $\mathrm{C}_{\mathrm{R}}$ \\
\hline Management Science & MS & 16 & 34.0 \\
European Journal of Operation Research & EJOR & 6 & 12.8 \\
Marketing Science & MKTSCl & 4 & 8.5 \\
International Journal of Production Economics & IJPE & 3 & 6.4 \\
Decision Science & DS & 2 & 4.3 \\
International Journal of Production Research & IJPR & 2 & 4.3 \\
Institute of Industrial Engineers Transactions & IIET & 1 & 2.1 \\
Journal of Operation Management & J OPER MANAG & 1 & 2.1 \\
Journal of Political Economy & J POLIT ECON & 1 & 2.1 \\
Manufacturing \& Service Operations Management & M\&SOM & 1 & 2.1 \\
MIT Sloan Management Review & SMR & 1 & 2.1 \\
\hline
\end{tabular}

$C_{A}=$ absolute number of citations received; $C_{R}=$ relative number of citations received based on 47 most cited works. 


\subsection{The intellectual foundation on CCC in 1JPE}

\subsubsection{Overall results}

The MDS map as illustrated in Figure 2 demonstrates the position of the 47 contributions on a two-dimensional MDS map. The sizes of the points indicate the absolute citation frequency and the distance of the documents indicates similarity or dissimilarity of the citation profile. The results of the MDS in combination with the results of the factor and cluster analysis can be interpreted as distinct specialties in the field (see e.g. McCain, 1990; White \&t McCain, 1998).
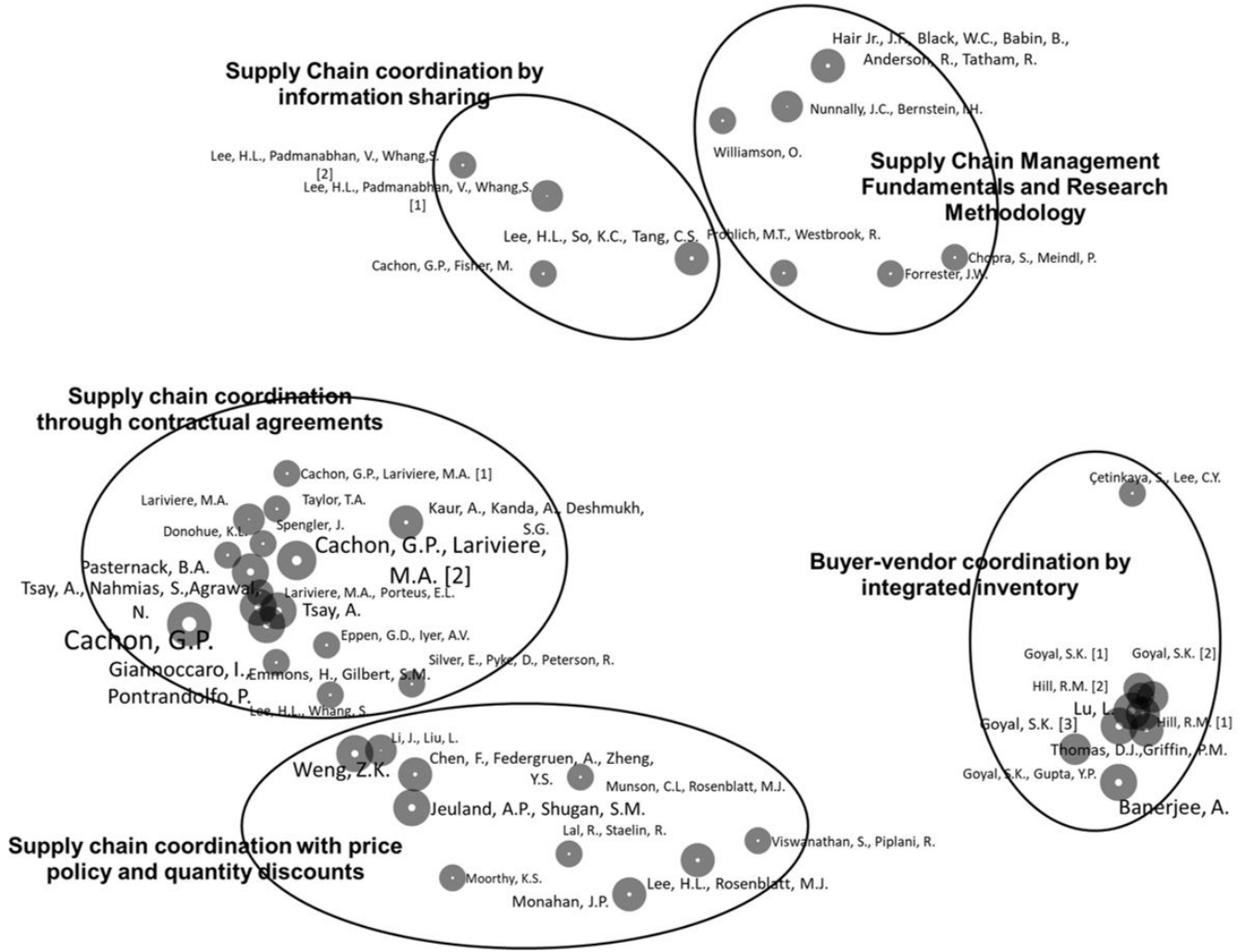

Figure 2. The intellectual structure of research on CCC.

In our case, we are able to see at least three and a maximum of seven thematic citation areas or groups. Based on our assessment we grouped them into five themes, visualized by circles and summarized them into categories as listed in Table 3.

Table 3. The intellectual structure of CCC research in IJPE - subject areas and contributing works; number in brackets indicates position of the author(s) in MDS.

\begin{tabular}{ll}
\hline \multicolumn{1}{c}{ Subject area } & \multicolumn{1}{c}{ Contributing Works } \\
\hline Buyer-vendor coordination by integrated inventory & $\begin{array}{l}\text { Banerjee (1986), Goyal (1977, 1988, 1995), Lu (1995), Goyal \& Gupta (1989), } \\
\text { Hill (1997, 1999), Thomas \& Griffin (1996), Çetinkaya \& Lee (2000) }\end{array}$ \\
$\begin{array}{ll}\text { Supply chain coordination with price policy and } \\
\text { quantity discounts }\end{array}$ & $\begin{array}{l}\text { (1984), Lee \& Rosenblatt (1986), Munson \& Rosenblatt (2001), Viswanathan \& Piplani } \\
\text { (2001), Li \& Liu (2006), Moorthy (1987) }\end{array}$ \\
& $\begin{array}{l}\text { Cachon (2003), Lariviere (1999), Spengler (1950), Pasternack (1985), Emmons \& Gilbert } \\
\text { (1998), Taylor (2002), Cachon \& Lariviere (2005, 2001), Donohue (2000), Tsay (1999), }\end{array}$ \\
$\begin{array}{l}\text { Supply chain coordination through contractual } \\
\text { agreements }\end{array}$ & $\begin{array}{l}\text { Eppen \& lyer (1997), Kaur et al. (2008), Tsay et al. (1999), Lariviere \& Porteus (2001), } \\
\text { Giannoccaro \& Pontrandolfo (2004), Lee \& Whang (1999), Silver et al. (1998) }\end{array}$ \\
$\begin{array}{l}\text { Supply chain coordination by information sharing } \\
\text { Supply Chain Management Fundamentals and }\end{array}$ & $\begin{array}{l}\text { Nunnally \& Bernstein (1978), Hair et al. (1998), Williamson (1985), Chopra \& Meindl } \\
\text { Research Methodology }\end{array}$ \\
\hline
\end{tabular}


Interestingly enough, our MDS does not show a central publication in terms of being positioned in the middle of the MDS. As we will show in the following, four of the five areas refer to specific coordination topics while one area refers to research methods. Such a pattern has also been identified by Georgi et al. (2010).

\subsubsection{Buyer-vendor coordination by integrated inventory}

This cluster is positioned in the lower right quadrant of the MDS and consists of 10 contributions published in different journals. The thematic focus of this group is on coordination of inventory between actors in a supply chain. The common theme is the development of mathematical models for inventory optimization. The identified papers were mainly published in EJOR followed by IJPR, Decision SCl and MS.

In total, 29 citations make Banerjee (1986) the most cited publication in this group which puts the publication under the four most cited papers (see Table 1). This publication deals with the development of a model to optimize the lot size between purchasers and vendors in a joint way. The overall goal is to minimize the total costs on both sides, the purchaser's as well as the seller's side. Very closely related to this paper are the works by Goyal $(1977,1988)$ where Goyal (1988) can be seen as a further development of Banerjee (1986) as the paper includes a further supplement on his mathematical model development. Goyal $(1977,1988)$ deal with the determination of an optimal inventory policy based on mathematical optimization.

$\mathrm{Lu}(1995)$ develops a heuristic model for an optimized inventory policy in a one-vendor multi-buyer setting and Goyal (1995) enlarges Lu's (1995) approach by suggesting an additional mathematical method for further minimizing the costs of both actors. Goyal \& Gupta (1989) analyse in their paper integrated inventory models from literature and develop a scheme for their classification.

Hill (1997) builds upon the notions of Goyal (1995, 1988, 1977), Banerjee (1986), Goyal \&t Gupta (1989) as well as Lu (1995) when developing an algorithm for the single-vendor single-buyer production inventory problem. Hill (1999) develops an innovative algorithm which considers a globally-optimal batching and shipping policy which aims at minimizing the mean total cost per unit time of a set-up, stock transfer and stock holding at a manufacturer's side. Thomas \& Griffin (1996) is an overview paper showing how inventory and operative supply chain costs can be lowered through mutual coordination for all supply chain actors.

Çetinkaya \& Lee (2000) hold a kind of outlier position in this group, however as they present a model for coordinating replenishment and shipment scheduling decisions in a vendor-managed inventory setting we included them in this group.

\subsubsection{Supply chain coordination with price policy and quantity discounts}

The group in the lower left quadrant of the MDS includes ten papers out of which four where published in MS, three in Market SCl and one in IEE Transactions as well as in EJOR and in IJPE. The thematic focus is on supply chain coordination by pricing policy, especially by discount policies. The papers discuss and show how to minimize costs through optimal production and inventory policies at supplier stages after having coordinated discount strategies with their customers. The majority of the papers introduce mechanisms, algorithms and mathematical programs to solve these issues.

The paper by Weng (1995) has an absolute citation frequency of 28 citations making this publication the most cited work in this group. The paper presents a model which is able to show the influence of a joint decision-making while coordinating the supply chain activities between a manufacturer and multiple homogenous customers. According to these authors quantity discounts and franchise fees drive supply chain coordination. The overall goal of the model is to reduce the operative costs for the manufacturer and its customers.

Jeuland \& Shugan (1983) published in $\mathrm{MKTSCl}$ and look at coordination problems in distribution channels. It asks the question whether quantity discounts can be used as coordination mechanism. Chen et al. (2001) built upon the notions of Jeuland \& Shugan (1983) as well as Tirole (1988) and examine coordination mechanisms in a specific distribution channel setting (one supplier - multiple retailers) by using a so-called non-traditional discount pricing scheme that regards a retailer's annual sales volume, order quantity and order frequency.

Monahan (1984) develops a mathematical model which considers quantity discounts for a higher order lot size which then results in reduced set up, ordering and inventory carrying costs for a supplier.

Lal \& Staelin (1984) - and later Chen et al. (2001) - look at optimal pricing policies which maximize the total supply chain profitability for all actors. The supply chain profits for a retailer is provided by a granted price discount, while manufacturers gain profitability through supply chain coordination in regards of order quantity, order frequency and annual sales numbers which allow cost reductions. 
The paper by lee \& Rosenblatt (1986) can be considered as a generalization of the Monahan (1984) quantity discount model. The authors show how quantity discounts increase the profits for vendors.

The paper by Munson \& Rosenblatt (2001) though focuses on supply chain coordination between three actors (supplier, manufacturer, retailer) and suggests a mechanism that can be used by firms for coordinating purchasing and production functions. While previous supply chain discount research looked at two-stage supply chains, Munson \& Rosenblatt (2001) extend this view to three stages.

Viswanathan \& Piplani (2001) propose in their paper a model for supply chain coordination of inventories by the use of common replenishment time periods. The vendor is offering thereby a price discount in order to make the buyer accept this strategy.

Li \& Liu (2006) develop a model that illustrates how to use quantity discount policy in order to achieve supply chain coordination in a supplier-buyer supply chain where one type of product is sold and probabilistic demand is considered. In order to achieve the best discount policy profit sharing is suggested.

Moorthy (1987) is a comment on Jeuland \& Shugan (1983) in which he criticizes their choice for discounts being only one of a multitude of a company's pricing policies, arguing that discounts are rather used for explaining price discrimination than channel coordination.

\subsubsection{Supply chain coordination through contractual agreements}

This coherent group of publications is positioned in the middle-left half of the MDS map and includes 17 papers representing more than a third of all citations which makes it the largest citation group. The majority of papers were published in MS followed by IJPE, Market SCI, MESOM and J POLIT ECON. Furthermore, this group includes three monographs and one handbook. The thematic focus of this group is on supply chain coordination through contracts based on inventory quantities and forecasts. This group also includes the two most cited papers by Cachon (2003; 47 citations) and Cachon \& Lariviere (2005; 36 citations).

We consider Cachon (2003) the most influential work in this area. It focusses on supply chain coordination via contracts. Supply chain members coordinate their activities by specific incentives which are determined by the contract partners. The overall goal is to improve the interaction between supply chain partners and to improve their supply chain performance.

An earlier paper which investigates these notions is given by Lariviere's (1999) monography. To him the coordination and evaluation of supplier contracts between independent supply chain actors is of central interest.

Interestingly enough the work by Spengler (1950) is also cited as it reflects antitrust policy in regards to vertical integration.

Contract structures are also discussed by Pasternack (1985) who looks at the coordination efforts between manufacturers and retailers when it comes to the return of perishable products. The overall idea is to measure the capacity of the distribution function as well as to minimize the losses due to returns resulting from a lack of coordination. This issue has also been addressed by Emmons \&t Gilbert (1998) who suggest a contract agreement on the control of production volumes in a supply chain.

Taylor (2002) though shows how to coordinate the sales volume of a manufacturer with a specific quantity discount system. Cachon \& Lariviere (2005) continue here and introduce how manufacturers and their customers can coordinate their supply chains via a revenue sharing contract.

The paper by Cachon \& Lariviere (2001) focusses on contractual issues when looking into stochastic demand forecast that can be periodically improved. The paper by Donohue (2000) shows how the coordination between forecast information and two-stage production decisions can be used to develop supplier contracts.

Tsay (1999) explains supply chain coordination by the means of a quantity flexibility contract which is based on forecast information by retailers. Thereby a fixed purchase quantity which is allowed to be below the forecast is guaranteed. The same is valid for the other side in order to capture uncertainties in demand fluctuations.

Eppen \&t lyer (1997) investigate the case of backup agreements where retailers and manufacturers close contracts in order to commit to a certain replenishment quantity while manufacturers hold back a constant fraction of the commitment. This policy shows to be profitable for all involved parties.

Kaur et al. (2008) present in their paper a state-of-the art on supply chain coordination and how research has addressed this problem so far. They discuss the various coordination mechanisms as well as difficulties in supply chain coordination. The main contribution however is the presentation of a model that helps to quantitatively assess the required mechanisms for supply chain coordination.

When it comes to a general overview on existing work on how to model supply chain contracts, we can consider Tsay et al. (1999) as being the fundamental one. Their work includes a systematic presentation of approaches dealing with supply chain contracts, their designs and coordination mechanisms. 
Lariviere \& Porteus (2001) analyse a price only contract in a news-vendor setting and develop a worst-case scenario for the analysis of supply chain performance.

Giannoccaro \& Pontrandolfo (2004) suggest a model of a supply chain contract with which central and local decision approaches can be coordinated. The model is based on revenue sharing in a three-echelon supply chain.

Lee \& Whang (1999) discuss in their paper incentive problems that arise if decisions were delegated to site managers in a supply chain that consists of multiple sites in series. Thereby problems of informational decentralisability properties as well as incentive misalignment may arise. In order to solve these problems, the authors propose alternative performance measurement schemes.

An interesting source in this group is represented by Silver et al. (1998), a textbook on inventory management, production planning and scheduling. One could expect such a work in another group that we identified which includes general textbooks. However, one could consider that the basic notions of Silver et al. (1998) are relevant for the generation of supply chain contracts that deal with replenishment situations.

\subsubsection{Supply chain coordination by information sharing}

This area is positioned in the upper left side of the MDS map and focusses on supply chain coordination through information interaction. The papers investigate mathematical models that capture interdependencies in supply chains and were published in MS and SLOAN MANAGE REV. The citation frequency of this small group consisting of four papers ranges between 11 and 17 citations. All papers are central when it comes to the notions of information sharing as well as the bullwhip effect.

The papers by Cachon \& Fisher (2000) and Lee et al. (2000, 1997a, b) examine the problems resulting from lack of information exchange in a supply chain setting. A focus is on demand, supply and operations planning under insufficient and distorted information interaction described as the bullwhip effect. The papers show the reasons of the creation of the bullwhip effect and suggest strategies for avoiding it by suggesting information sharing strategies.

\subsubsection{Supply chain management fundamentals and research methodology}

The papers positioned in the upper right part of the MDS map represent two categories which we opted to put into one group that is, dealing with general notions on supply chain classifications as well as methodological and theoretical fundamentals. This group includes five books and one J OPER MANAG article.

The methodological publications include the work by Nunnally \& Bernstein (1978) which can be considered as a standard textbook for development and testing theory for empirical research. The work by Hair et al. (1998) is a standard textbook for multivariate data analysis. When it comes to the theoretical fundamentals, we are able to identify Williamson's (1985) standard work introducing transaction cost theory, which is for sure an important source when it comes to supply chain coordination. Furthermore, it looks like that Chopra \& Meindl (2001) is considered to be the standard supply chain management textbook here. Interestingly, the text by Forrester (1961) on Industrial Dynamics, which can be seen as the first source that discusses the bullwhip effect, is also used as a central source for examining the effects of coordination in supply chains.

In addition, the work by Frohlich \& Westbrook (2001) is used as a major source when it comes to supply chain integration activities.

\section{Discussion}

Our study provides a comprehensive overview on the intellectual foundation of CCC related research which we need to limit to- based on our results -Coordination research as Collaboration as well as Cooperation related papers were not amongst the most cited papers.

The identified citation subfields reflect some of the supply chain coordination mechanisms as shown by Kaur et al. (2008), in particular supply chain contracts, information sharing and joint decision making. Within the citation subfields we observe a high number of citations in regards to contractual agreements which could be interpreted as an indicator for the research interest within the area and/or the importance of this coordination mechanism as perceived by the researchers in the field. Nevertheless, when comparing the five groups as shown in the MDS-map, there are distinct patterns allowing insights about citation behaviour of IJPE authors and providing hints for future research.

The group on "Buyer-vendor coordination by integrated inventory" combines articles, which are very close to each other, which might reflect the authorship situation as four papers are (co-) authored from Goyal (see Goyal, 
1977, 1988, 1995; Goyal \& Gupta, 1989). At first, papers, which are frequently cited, have been published in the late eighties. Later on, authors seem to acknowledge another wave of articles in the second half of the nineties. This group is rather distant from the other two pairs of groups. This pattern can be interpreted in different ways. It seems that this field is dominated by a very narrow field of authors and approaches with no dominant links to other research areas and no mayor citation-relevant findings after the year 2000. However, it may also be that other papers were not able yet to reach the required impact in terms of citation frequency. This would however provide evidence for diversity in the use of citations.

The group on "Supply chain coordination with price policy and quantity discounts" presents in terms of authorships a much more diverse picture than the first group on "buyer-vendor coordination". In addition, the publications show more distance among themselves, compared to the very closely related publication of the first group. Hence, IJPE authors citing publications in this cluster lean on a variance of foundational research. Mayor break-through research as acknowledged by IJPE authors happened in the mid of eighties and then again 2001 and 2006. Hence, the IJPE authors in this area do not seem to value research published for the 15-year period in between, with one exception (Weng, 1995). Additionally, the group is close to the third group on contractual agreements. Researchers and practitioners, who want to lean on this cluster, might need to be very selective, which part of the diverse research field is valuable as a foundation for their own insights. Taking into consideration many of the different aspects might blur the foundational focus. Additionally, leaning into the foundational literature of the cluster on contractual agreements might add value in some distinct cases.

The third cluster "Supply chain coordination through contractual agreements" reflects a group of very closely linked publications as well as a decently diverse set of publications - as utilized by IJPE authors. The two articles by Tsay (1999) and Tsay et al. (1999) seem to be the focal works for researchers in this area. Interestingly, the two works by Cachon (2003) and Cachon \& Lariviere (2005) rather show the spread of the cluster. We also see in this cluster various combinations of co-authors, reflecting an interactive publishing community. Furthermore, the articles by Lee \& Whang (1999) and Silver et al. (1998) are very close to the cluster on "coordination with price policy". Hence, we can see the closeness between the two clusters and their usage for citations in IJPE research. Researchers in the field, might need to be very distinct, on their contribution, when there are working close to the "core" of this cluster as obviously much research has been published in this area. Nevertheless, the rather strong citations of some more distant articles provide a hint, that there are specific research areas, which can contribute to the whole cluster topic, e.g. revenue sharing aspects (see Cachon \&t Lariviere, 2005), including empirical research (Kaur et al., 2008) or Back-up agreements (see Eppen \&t lyer, 1997).

We have a rather spread out fourth cluster on "Supply chain coordination by information sharing" with only four articles and seven contributing authors. This is a rather unique situation compared to the other four clusters shown in this research documentation. 1JPE authors seem to acknowledge these in 1997 and 2000 published papers, almost all published in Management Science, one in Sloan Management Review. Nevertheless, the researchers do not show a distinct pattern of citing any other articles as well. As this cluster is close to the cluster on "Supply Chain Management Fundamentals and Research Methodology" the explanation might be, that papers are used for motivating the research on the topic in general, but then IJPE authors move on to more specific research streams to underpin their articles.

The fifth cluster which we identified represents publications which can be interpreted as the enablers of rigorous research. These papers represent fundamentals for developing valid and reliable constructs that can be empirically tested as well as for analysing empirical results in an adequate manner. Hence, the articles in this cluster might have a similar usage by IJPE authors as the articles of the fourth cluster. In addition, this fifth cluster shows rather distant relationships among the six works - so a similar pattern as the fourth cluster. For authors thinking about publishing in this journal, these are guardrails for providing a foundation in terminology and methodical rigour as expected by the reviewers and editorial board.

\section{Conclusion and outlook}

Our findings show that the works under investigation on supply chain coordination can be considered to be fundamental and central for CCC research within IJPE as they were also used by other papers which we identified for our citation and co-citation analysis. From a scientific knowledge creation perspective, we can evaluate these linkages between the various articles as being fruitful for theory and methodological development in the field. The visualisation of our results in the MDS-map allowed for a thematic grouping as well as an identification of the problem areas in regards to coordination, cooperation and collaboration in a supply chain setting. Thereby we can identify a clear dominance on supply chain coordination and a lack of works dealing with supply chain cooperation and collaboration or rather logistics-oriented topics. 
The results of the citation analysis showed that the five most cited paper are by Cachon (2003), followed by Cachon \& Lariviere (2005), Banerjee (1986), Weng (1995) and Giannoccaro \&t Pontrandolfo (2004), where the latter was published in IJPE. The most common used journal source for CCC research in IJPE is MS followed by EJOR, Market $\mathrm{SCl}$ and IJPE. This also allows a statement on the methodological understanding of CCC research in IJPE which is more modelling than empirical.

Our Co-citation analysis presents five citation groups out of which four represent coordination mechanisms as indicated by Kaur et al. (2008). However, while Kaur et al. (2008) see discounts as part of contracts, our results suggested to distinguish this part of supply chain coordination into two groups (supply chain coordination through contractual agreements and by price policy and quantity discounts).

Reflecting the recognised citation clusters with the framework as outlined in Figure 1, we are able to establish a linkage between the four groups of 'supply chain coordination by information sharing', 'supply chain coordination through contractual agreements', 'supply chain coordination with price policy and quantity discounts' and 'buyer-vendor coordination by integrated inventory' with the collaborative elements of 'information exchange' and 'joint partnership management system. The remaining relationship elements of 'trust', 'relation specific asset', and 'partner asymmetry' cannot be developed in a negligible way.

Overall, in this research community we identify the coordination- $C$ as the dominant group which could be a result of a lack of selectivity in the use of the three terms examined in more detail here. A closer look at our sample shows that a large share of these articles deals with supply chain coordination issues which proofs the major interest in this particular area within supply chain research.

There are some limitations which we need to address. First, our analysis is based on the citation structure of one journal, which we considered as one particular research domain. This may be the reason for the identified emphasis on supply chain coordination and the lack of supply chain cooperation and collaboration. Consequently, we suggest making a comparative study by analysing the intellectual foundation of other journals, which are rather representing a managerial perspective. A first attempt in this direction is shown by Kotzab et al. (2018) who analysed more than 74,000 citations on CCC of more than 3,000 articles published in more than 40 journals between 1991 and 2015. They confirm the results which are presented in this paper as coordination is the dominating theme and it seems that the various use of CCC depends on the research community and its isolated use of literature.

A second limitation refers to the time frame of our analysis which only allowed a static analysis; a dynamic comparison of different time periods is lacking. We did not include such a dynamic view due to the number of articles that we identified in the first step. Any division of this sample would have led to very low case numbers. We are however aware that a dynamic view would have offered a change in the use of citations as well as in the thematic themes which are reflected by the citations. Future research might have this in mind.

Since our study only provides a snapshot, we hope that comparable studies will be carried out regularly in the future in order to keep track of the evolution of research in this field.

\section{References}

Albino, V., Carbonara, N., \& Giannoccaro, 1. (2007). Supply chain cooperation in industrial districts: a simulation analysis. European Journal of Operational Research, 177(1), 261-280. http://dx.doi.org/10.1016/j.ejor.2005.12.007.

Assad, A., \& Golden, B. (1982). A categorized bibliography of survey articles in management science and operations research. Management Science, 28, 425-438.

Baier-Fuentes, H., Merigó, J. M., Amorós, J. E., \& Gaviria-Marín, M. (2019). International entrepreneurship: a bibliometric overview. The International Entrepreneurship and Management Journal, 15(2), 385-429. http://dx.doi.org/10.1007/s11365-017-0487-y.

Banerjee, A. (1986). A joint economic-lot-size model for purchaser and vendor. Decision Sciences, 17(3), 292-311. http://dx.doi. $\operatorname{org} / 10.1111 /$ j.1540-5915.1986.tb00228.x.

Banker, R. D., \& Kauffman, R. J. (2004). The evolution of research on information systems: a fiftieth-year survey of the literature in management science. Management Science, 50(3), 281-298. http://dx.doi.org/10.1287/mnsc.1040.0206.

Barratt, M. (2004). Understanding the meaning of collaboration in the supply chain. Supply Chain Management: An International Journal, 9(1), 30-42. http://dx.doi.org/10.1108/13598540410517566.

Bowersox, D. J. (1990). The strategic benefits of logistics alliances. Harvard Business Review, 68(4), 36-45.

Burke, G. J., Arora, A., \& Raisinghani, M. S. (2012). Measuring the effect of supply chain collaborations and market turbulence on performance outcomes. In International Technology Management Conference (pp. 188-196). New York: IEEE. http://dx.doi. org/10.1109/ITMC.2012.6306397.

Cachon, G. P. (2003). Supply chain coordination with contracts. In S. C. Graves \& A. G. Kok (Eds.), Supply chain management: design, coordination and operation (pp. 227-339). Amsterdam: Elsevier. http://dx.doi.org/10.1016/S0927-0507(03)11006-7. 
Cachon, G. P., \& Fisher, M. (2000). Supply chain inventory management and the value of shared information. Management Science, 46(8), 1032-1048. http://dx.doi.org/10.1287/mnsc.46.8.1032.12029.

Cachon, G. P., \& Lariviere, M. A. (2001). Contracting to assure supply: how to share demand forecasts in a supply chain. Management Science, 47(5), 629-646. http://dx.doi.org/10.1287/mnsc.47.5.629.10486.

Cachon, G. P., \& Lariviere, M. A. (2005). Supply chain coordination with revenue-sharing contracts: strengths and limitations. Management Science, 51(1), 30-44. http://dx.doi.org/10.1287/mnsc.1040.0215.

Cao, M., Vonderembse, M. A., Zhang, Q., \& Ragu-Nathan, T. S. (2010). Supply chain collaboration: conceptualisation and instrument development. International Journal of Production Research, 48(22), 6613-6635. http://dx.doi.org/10.1080/00207540903349039.

Çetinkaya, S., \& Lee, C.-Y. (2000). Stock replenishment and shipment scheduling for vendor-managed inventory systems. Management Science, 46(2), 217-232. http://dx.doi.org/10.1287/mnsc.46.2.217.11923.

Chen, F., Federgruen, A., \& Zheng, Y.-S. (2001). Coordination mechanisms for a distribution system with one supplier and multiple retailers. Management Science, 47(5), 693-708. http://dx.doi.org/10.1287/mnsc.47.5.693.10484.

Chopra, S., Meindl, P. (2001). Supply chain management: strategy, planning, and operation. New Jersey: Pearson Prentice Hall.

Clemons, E. K., \& Row, M. C. (1992). Information technology and industrial cooperation: the changing economics of coordination and ownership. Journal of Management Information Systems, 9(2), 9-28. http://dx.doi.org/10.1080/07421222.1992.11517956.

Darkow, l.-L., Georgi, C., \& Kotzab, H. (2010). Strukturen der logistik \& supply chain forschung: eine bibliometrische analyse. Copenhagen: Copenhagen Business School.

Ding, H., Guo, B., \& Liu, Z. (2011). Information sharing and profit allotment based on supply chain cooperation. International Journal of Production Economics, 133(1), 70-79. http://dx.doi.org/10.1016/j.jpe.2010.06.015.

Donohue, K. L. (2000). Efficient supply contracts for fashion goods with forecast updating and two production modes. Management Science, 46(11), 1397-1411. http://dx.doi.org/10.1287/mnsc.46.11.1397.12088.

EBSCO. (2016). Business source complete. Massachusetts: EBSCO. Retrieved in 2016, November 8, from https://www.ebscohost.com/ academic/business-source-complete

El Omri, A. (2009). Cooperation in supply chains: alliance formatin and profit allocation among independent firms. France: École Centrale Paris.

Ellram, L. M., \& Cooper, M. C. (1990). Supply chain management, partnerships, and the shipper: third party relationship. International Journal of Logistics Management, 1(2), 1-10. http://dx.doi.org/10.1108/95740939080001276.

Emmons, H., \& Gilbert, S. M. (1998). Note: the role of returns policies in pricing and inventory decisions for catalogue goods. Management Science, 44(2), 276-283. http://dx.doi.org/10.1287/mnsc.44.2.276.

Eom, S. (2008). Author cocitation analysis: quantitative methods for mapping the intellectual structure of an academic discipline. New York: $1 \mathrm{Gl}$ Global.

Eppen, G. D., \& lyer, A. V. (1997). Backup agreements in fashion buying: the value of upstream flexibility. Management Science, 43(11), 1469-1484. http://dx.doi.org/10.1287/mnsc.43.11.1469.

Fawcett, S. E., Magnan, G. M., \& Williams, A. J. (2004). Supply chain trust is within your grasp. Supply Chain Management Review, $8(2), 20-26$.

Forrester, J. W. (1961). Industrial dynamics. New York: Wiley.

Frankel, R., Bolumole, Y. A., Eltantawy, R. A., Paulraj, A., \& Gundlach, G. T. (2008). The domain and scope of SCM's foundational disciplines: insights and issues to advance research. Journal of Business Logistics, 29(1), 1-30. http://dx.doi.org/10.1002/j.2158-1592.2008. tb00066.x.

Frohlich, M. T., \& Westbrook, R. (2001). Arcs of integration: an international study of supply chain strategies. Journal of Operations Management, 19(2), 185-200. http://dx.doi.org/10.1016/S0272-6963(00)00055-3.

Fugate, B., Sahin, F., \& Mentzer, J. T. (2006). Supply chain management coordination mechanisms. Journal of Business Logistics, 27(2), 129-161. http://dx.doi.org/10.1002/j.2158-1592.2006.tb00220.x.

Garfield, E. (1979). Is citation analysis a legitimate evaluation tool? Scientometrics, 1(4), 359-375. http://dx.doi.org/10.1007/BF02019306.

Georgi, C., Darkow, 1.-L., \& Kotzab, H. (2010). The intellectual foundation of the journal of business logistics and its evolution between 1978 and 2007. Journal of Business Logistics, 31(2), 63-109. http://dx.doi.org/10.1002/j.2158-1592.2010.tb00143.x.

Georgi, C., Darkow, 1.-L., \& Kotzab, H. (2013). Foundations of logistics and supply chain research: a bibliometric analysis of four international journals. International Journal of Logistics Research and Applications, 16(6), 522-533. http://dx.doi.org/10.1080/13 675567.2013.846309.

Giannoccaro, 1., \& Pontrandolfo, P. (2004). Supply chain coordination by revenue sharing contracts. International Journal of Production Economics, 89(2), 131-139. http://dx.doi.org/10.1016/S0925-5273(03)00047-1.

Göpfert, 1. (2016). Logistik der zukunft-Logistics for the future. Wiesbaden: Springer. http://dx.doi.org/10.1007/978-3-658-12256-0.

Goyal, S. K. (1977). An integrated inventory model for a single supplier-single customer problem. International Journal of Production Research, 15(1), 107-111. http://dx.doi.org/10.1080/00207547708943107.

Goyal, S. K. (1988). A joint economic-lot-size model for purchaser and vendor. Decision Sciences, 19(1), 236-241. http://dx.doi. $\operatorname{org} / 10.1111 / j .1540-5915.1988 . t b 00264 . x$.

Goyal, S. K. (1995). A one-vendor multi-buyer integrated inventory model: a comment. European Journal of Operational Research, 82(1), 209-210. http://dx.doi.org/10.1016/0377-2217(93)E0357-4.

Goyal, S. K., \& Gupta, Y. P. (1989). Integrated inventory models: the buyer-vendor coordination. European Journal of Operational Research, 41(3), 261-269. http://dx.doi.org/10.1016/0377-2217(89)90247-6.

Grubbström, R. W. (2016). Author information pack. International Journal of Production Economics. Retrieved in 2016, November 8 , from https://www.journals.elsevier.com/international-journal-of-production-economics

Hair, J. F., Black, W. C., Babin, B. J., \& Anderson, R. E. (2014). Multivariate data analysis. Harlow: Pearson. 
Hair, J., Tatham, R., Anderson, R., \& Black, W. (1998). Multivariate data analysis (5th ed.). New Jersey: Prentice Hall.

Harzing, A.-W. (2016). Journal Quality List (57th ed.). Harzing.com.

Heide, J. B., \& Miner, A. S. (1992). The shadow of the future: effects of anticipated interaction and frequency of contact on buyer-seller cooperation. Academy of Management Journal, 35(2), 265-291. http://dx.doi.org/10.5465/256374.

Hill, C. E., Thompson, B. J., \& Williams, E. N. (1997). A guide to conducting consensual qualitative research. The Counseling Psychologist, 25(4), 517-572. http://dx.doi.org/10.1177/0011000097254001.

Hill, R. M. (1997). The single-vendor single-buyer integrated production-inventory model with a generalised policy. European Journal of Operational Research, 97(3), 493-499. http://dx.doi.org/10.1016/S0377-2217(96)00267-6.

Hill, R. M. (1999). The optimal production and shipment policy for the single-vendor singlebuyer integrated production-inventory problem. International Journal of Production Research, 3711), 2463-2475. http://dx.doi.org/10.1080/002075499190617.

Hoffman, D. L., \& Holbrook, M. B. (1993). The intellectual structure of consumer research: a bibliometric study of author cocitations in the first 15 years of the journal of consumer research. The Journal of Consumer Research, 19(4), 505-517. http://dx.doi. org/10.1086/209319.

Hopp, W. J. (2004). Fifty years of management science. Management Science, 50(1), 1-7. http://dx.doi.org/10.1287/mnsc.1030.0181.

Horvath, L. (2001). Collaboration: the key to value creation in supply chain management. Supply Chain Management: An International Journal, 6(5), 205-207. http://dx.doi.org/10.1108/EUM0000000006039.

Houlihan, J. B. (1985). International supply chain management. International Journal of Physical Distribution \& Materials Management, 15(1), 22-38. http://dx.doi.org/10.1108/eb014601.

Jeuland, A. P., \& Shugan, S. M. (1983). Managing channel profits. Marketing Science, 2(3), 239-272. http://dx.doi.org/10.1287/ mksc.2.3.239.

Jones, T. C., \& Riley, D. W. (1985). Using inventory for competitive advantage through supply chain management. International Journal of Physical Distribution \& Materials Management, 15(5), 16-26. http://dx.doi.org/10.1108/eb014615.

Kaur, A., Kanda, A., \& Deshmukh, S. G. (2008). Supply chain coordination: perspectives, empirical studies and research directions. International Journal of Production Economics, 115(2), 316-335. http://dx.doi.org/10.1016/j.jpe.2008.05.011.

Kaur, A., Kanda, A., \& Deshmukh, S. G. (2011). A review on supply chain coordination: coordination mechanisms, managing uncertainty and research directions. In T.-M. Choi \& T. C. E. Cheng (Eds.), Supply chain coordination under uncertainty, international handbooks on information systems (pp. 39-82). Berlin: Springer. http://dx.doi.org/10.1007/978-3-642-19257-9_3.

Kim, K. K., \& Umanath, N. S. (2005). Information transfer in B2B procurement: an empirical analysis and measurement. Information \& Management, 42(6), 813-828. http://dx.doi.org/10.1016/j.im.2004.08.004.

Kotzab, H., \& Biedermann, L. (2018). Die strategische bedeutung des supply chain managements. In H. Corsten, R. Gössinger \& T. S. Spengler (Eds.), Handbuch produktions- und logistikmanagement in wertschöpfungsnetzwerken. Berlin: De Gruyter. http://dx.doi. org/10.1515/9783110473803-004.

Kotzab, H., \& Otto, A. (2004). General process-oriented management principles to manage supply chains: theoretical identification and discussion. Business Process Management Journal, 10(3), 336-349. http://dx.doi.org/10.1108/14637150410539731.

Kotzab, H., Darkow, l.-L., Bäumler, l., Georgi, C., \& Luttermann, S. 2018. Mapping research on logistics and supply chain coordination, cooperation and collaboration. In M. Freitag, H. Kotzab \& J. Pannek (Eds.), Dynamics in logistics (pp. 10-20). Cham: Springer International Publishing. http://dx.doi.org/10.1007/978-3-319-74225-0_2.

Kruskal, J. B. (1964a). Multidimensional scaling by optimizing goodness of fit to a nonmetric hypothesis. Psychometrika, 29(1), 1-27. http://dx.doi.org/10.1007/BF02289565.

Kruskal, J. B. (1964b). Nonmetric multidimensional scaling: a numerical method. Psychometrika, 29(2), 115-129. http://dx.doi. org/10.1007/BF02289694.

Lal, R., \& Staelin, R. (1984). An approach for developing an optimal discount pricing policy. Management Science, 30(12), $1524-1539$. http://dx.doi.org/10.1287/mnsc.30.12.1524.

LaLonde, B. J., \& Masters, J. M. (1990). Logistics: perspectives for the 1990s. International Journal of Logistics Management, 1(1), 1-6. http://dx.doi.org/10.1108/09574099010804482.

Lariviere, M. A. (1999). Supply chain contracting and coordination with stochastic demand. In S. Tayur, R. Ganeshan \& M. Magazine (Eds.), Quantitative Models for Supply Chain Management (International Series in Operations Research \& Management Science, pp. 233-268). New York: Springer. http://dx.doi.org/10.1007/978-1-4615-4949-9_8.

Lariviere, M. A., \& Porteus, E. L. (2001). Selling to the newsvendor: an analysis of price-only contracts. Manufacturing \& Service Operations Management, 3(4), 293-305. http://dx.doi.org/10.1287/msom.3.4.293.9971.

Lee, H. L., \& Rosenblatt, M. J. (1986). A generalized quantity discount pricing model to increase supplier's profits. Management Science, 32(9), 1177-1185. http://dx.doi.org/10.1287/mnsc.32.9.1177.

Lee, H. L., Padmanabhan, V., \& Whang, S. (1997a). Information distortion in a supply chain: the bullwhip effect. Management Science, 43(4), 546-558. http://dx.doi.org/10.1287/mnsc.43.4.546.

Lee, H. L., Padmanabhan, V., \& Whang, S. (1997b). The bullwhip effect in supply chains. Sloan Management Review, 38, 93-102.

Lee, H. L., So, K. C., \& Tang, C. S. (2000). The value of information sharing in a two-level supply chain. Management Science, 46(5), 626-643. http://dx.doi.org/10.1287/mnsc.46.5.626.12047.

Lee, H., \& Whang, S. (1999). Decentralized multi-echelon supply chains: incentives and information. Management Science, 45(5), 633640. http://dx.doi.org/10.1287/mnsc.45.5.633.

Li, J., \& Liu, L. (2006). Supply chain coordination with quantity discount policy. International Journal of Production Economics, 101(1), 89-98. http://dx.doi.org/10.1016/j.jpe.2005.05.008.

Lindquist, T. M., \& Smith, G. (2009). Journal of Management Accounting Research: content and citation analysis of the first 20 years. Journal of Management Accounting Research, 21(1), 249-292. http://dx.doi.org/10.2308/jmar.2009.21.1.249. 
Lu, L. (1995). A one-vendor multi-buyer integrated inventory model. European Journal of Operational Research, 81(2), 312-323. http:// dx.doi.org/10.1016/0377-2217(93)E0253-T.

Maloni, M., \& Benton, W. C. (2000). Power influence in the supply chain. Journal of Business Logistics, 21(1), 49-73.

McCain, K. W. (1990). Mapping authors in intellectual space: a technical overview. Journal of the American Society for Information Science, 41(6), 433-443. http://dx.doi.org/10.1002/(SICl)1097-4571(199009)41:6<433::AID-ASI11>3.0.C0;2-Q.

Mentzer, J. T., DeWitt, W., Keebler, J. S., Min, S., Nix, N. W., Smith, C. D., \& Zacharia, Z. G. (2001). Defining supply chain management. Journal of Business Logistics, 22(2), 1-25. http://dx.doi.org/10.1002/j.2158-1592.2001.tb00001.x.

Mentzer, J. T., Stank, T. P., \& Esper, T. L. (2008). Supply chain management and its relationship to logistics, marketing, production, and operations management. Journal of Business Logistics, 29(1), 31-46. http://dx.doi.org/10.1002/j.2158-1592.2008.tb00067.x.

Min, S., Roath, A. S., Daugherty, P. J., Genchev, S. E., Chen, H., Arndt, A. D., \& Glenn Richey, R. (2005). Supply chain collaboration: what's happening? International Journal of Logistics Management, 16(2), 237-256. http://dx.doi.org/10.1108/09574090510634539.

Monahan, J. P. (1984). A quantity discount pricing model to increase vendor profits. management Science, 30(6), 720-726. http:// dx.doi.org/10.1287/mnsc.30.6.720.

Monczka, R. M., Handfield, R. B., Giunipero, L. C., \& Patterson, J. L. (2009). Purchasing and supply chain management (4th ed.). Mason: South-Western Cengage Learning.

Moorthy, K. S. (1987). Comment: managing channel profits. Marketing Science, 6(4), 375-379. http://dx.doi.org/10.1287/mksc.6.4.375.

Munson, C. L., \& Rosenblatt, M. J. (2001). Coordinating a three-level supply chain with quantity discounts. IIE Transactions, 33(5), 371-384. http://dx.doi.org/10.1080/07408170108936836.

Nunnally, J. C., \& Bernstein, 1. (1978). Psychometric theory. New York: McGraw-Hill.

Parkhe, A. (1991). Interfirm diversity, organizational learning, and longevity in global strategic alliances. Journal of International Business Studies, 22(4), 579-601. http://dx.doi.org/10.1057/palgrave.jibs.8490315.

Pasternack, B. A. (1985). Optimal pricing and return policies for perishable commodities. Marketing Science, 4(2), 166-176. http:// dx.doi.org/10.1287/mksc.4.2.166.

Ramos-Rodríguez, A.-R., \& Ruíz-Navarro, J. (2004). Changes in the intellectual structure of strategic management research: a bibliometric study of the Strategic Management Journal, 1980-2000. Strategic Management Journal, 25(10), 981-1004. http:// dx.doi.org/10.1002/smj.397.

Ryu, K., Moon, l., Oh, S., \& Jung, M. (2013). A fractal echelon approach for inventory management in supply chain networks. International Journal of Production Economics, 143(2), 316-326. http://dx.doi.org/10.1016/j.jpe.2012.01.002.

Silver, E. A., Pyke, D. F., \& Peterson, R. (1998). Inventory management and production planning and scheduling (3rd ed.). New York: Wiley.

Smith, D. R. (2009). A 30-year citation analysis of bibliometric trends at the Archives of Environmental Health, 1975-2004. Archives of Environmental \& Occupational Health, 64(Suppl 1), 43-54. http://dx.doi.org/10.1080/19338240903293004. PMid:20007116.

Smith, L. C. (1981). Citation analysis. Library Trends, 30, 83-106.

Son, B.-G. (2004). Managing a successful supply chain partnership (PhD thesis). City University London, London.

Spengler, J. J. (1950). Vertical integration and antitrust policy. Journal of Political Economy, 58(4), 347-352. http://dx.doi.org/10.1086/256964.

Stevens, G. C. (1989). Integrating the supply chain. International Journal of Physical Distribution \& Materials Management, 19(8), 3-8. http://dx.doi.org/10.1108/EUM0000000000329.

Stuart, F. l. (1997). Supply-chain strategy: organizational influence through supplier alliances. British Journal of Management, $8(3)$, 223-236. http://dx.doi.org/10.1111/1467-8551.00062.

Taylor, T. A. (2002). Supply chain coordination under channel rebates with sales effort effects. Management Science, 48(8), 992-1007. http://dx.doi.org/10.1287/mnsc.48.8.992.168.

Thomas, D. J., \& Griffin, P. M. (1996). Coordinated supply chain management. European Journal of Operational Research, 94(1), 1-15. http://dx.doi.org/10.1016/0377-2217(96)00098-7.

Tirole, J. (1988). The theory of industrial organization. Cambridge: MIT Press.

Tsay, A. A. (1999). The quantity flexibility contract and supplier-customer incentives. Management Science, 45(10), 1339-1358. http:// dx.doi.org/10.1287/mnsc.45.10.1339.

Tsay, A. A., Nahmias, S., \& Agrawal, N. (1999). Modeling supply chain contracts: a review. In S. Tayur, R. Ganeshan \& M. Magazine (Eds.), Quantitative models for supply chain management (International Series in Operations Research \& Management Science, pp. 299-336). New York: Springer. http://dx.doi.org/10.1007/978-1-4615-4949-9_10.

Viswanathan, S., \& Piplani, R. (2001). Coordinating supply chain inventories through common replenishment epochs. European Journal of Operational Research, 129(2), 277-286. http://dx.doi.org/10.1016/S0377-2217(00)00225-3.

Weng, Z. K. (1995). Channel coordination and quantity discounts. Management Science, 41(9), 1509-1522. http://dx.doi.org/10.1287/ mnsc.41.9.1509.

White, H. D., \& Griffith, B. C. (1981). Author cocitation: a literature measure of intellectual structure. Journal of the American Society for Information Science, 32(3), 163-171. http://dx.doi.org/10.1002/asi.4630320302.

White, H. D., \& McCain, K. W. (1998). Visualizing a discipline: an author co-citation analysis of information science, 1972-1995. Journal of the American Society for Information Science, 49, 327-355.

Williamson, O. E. (1985). The economic institutions of capitalism: firms, markets, relational contracting. New York: Free Press.

Zupic, l., \& Čater, T. (2015). Bibliometric methods in management and organization. Organizational Research Methods, 18(3), 429-472. http://dx.doi.org/10.1177/1094428114562629. 
Appendix A. Dendrogram of the 47 most-cited publications in research on CCC, using complete-linkage as hierarchical clustering algorithm.

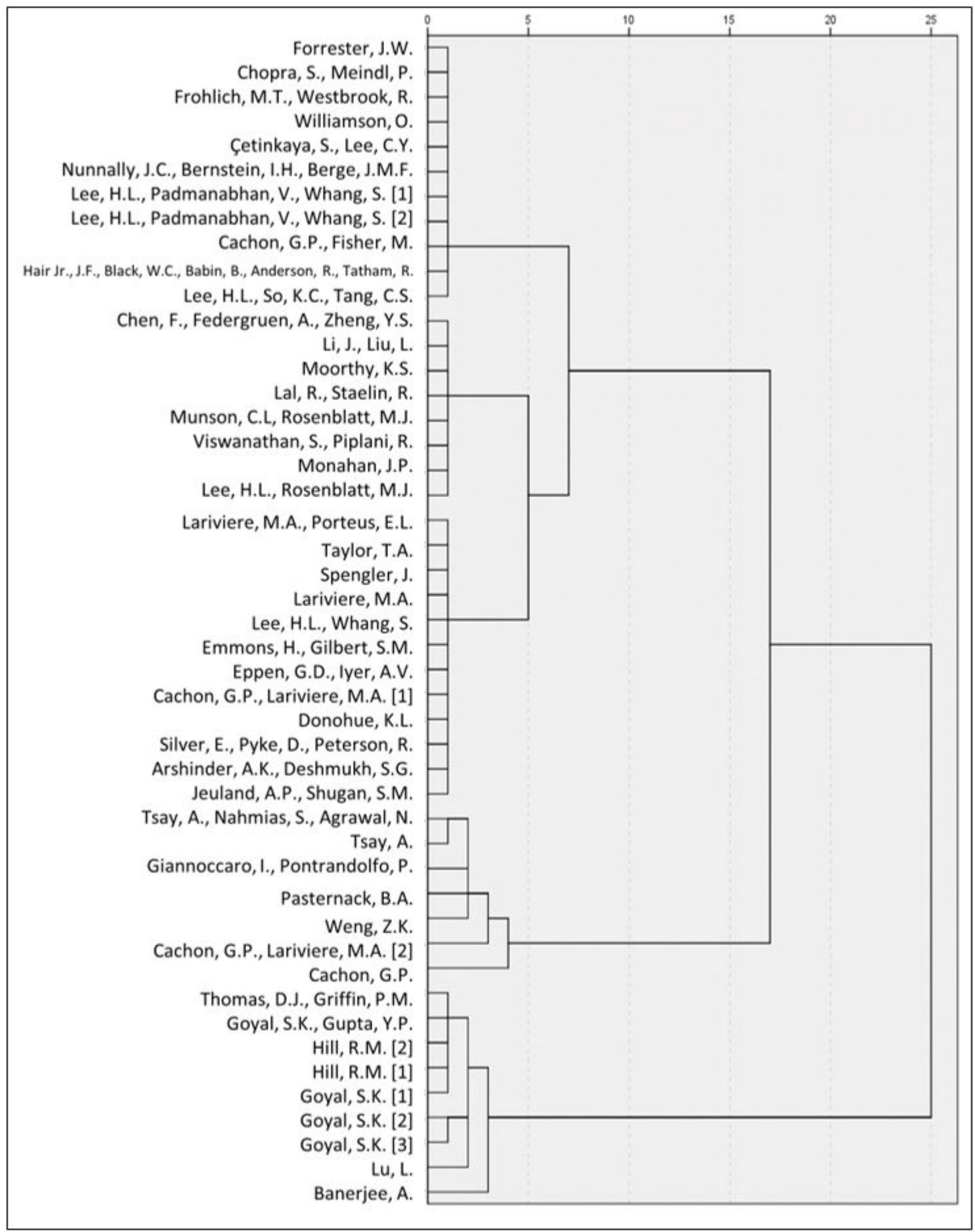


Appendix B. Factor analysis of the 47 most-cited publications in research on CCC; loadings higher than 0.5 are indicated. Rotated component matrix ${ }^{\mathrm{a}}$

\begin{tabular}{|c|c|c|c|c|c|c|c|}
\hline & \multicolumn{7}{|c|}{ Component } \\
\hline & 1 & 2 & 3 & 4 & 5 & 6 & 7 \\
\hline Supply chain coordination under channel rebates with sales effort effects & .889 & & & & & & \\
\hline Selling to the newsvendor: An analysis of price only contracts & .882 & & & & & & \\
\hline Vertical integration and antitrust policy & .878 & & & & & & \\
\hline Supply chain contracting and coordination with stochastic demand & .865 & & & & & & \\
\hline Modeling supply chain contracts: a review & .846 & & & & & & \\
\hline $\begin{array}{l}\text { Efficient supply contracts for fashion goods with forecast updating and two } \\
\text { production modes }\end{array}$ & .825 & & & & & & \\
\hline $\begin{array}{l}\text { Supply chain coordination with revenue sharing contracts: strengths and } \\
\text { limitations }\end{array}$ & .818 & & & & & & \\
\hline Optimal pricing and return policies for perishable commodities & .808 & & & & & & \\
\hline Contracting to assure supply: How to share demand forecasts in a supply chain & .767 & & & & & & \\
\hline The quantity flexibility contract and supplier-customer incentives & .763 & & & & & & \\
\hline The role of returns policies in pricing and inventory decisions for catalogue goods & .760 & & & & & & \\
\hline Supply chain coordination: perspective, empirica lstudies and research directions & .730 & & & & & & \\
\hline Supply chain coordination by revenue sharing contract & .677 & & & & & & \\
\hline Supply chain coordination with contracts & .649 & & & & & & \\
\hline Backup agreements in fashion buying-the value of upstream flexibility & .638 & & & & & & \\
\hline Inventory Management and Production Planning and Scheduling & .599 & & .551 & & & & \\
\hline Decentralized multi echelon supply chains: incentives and information & .574 & & .566 & & & & \\
\hline $\begin{array}{l}\text { The optimal production and shipment policy for the single vendor single buyer } \\
\text { integrated production inventory model }\end{array}$ & & .918 & & & & & \\
\hline A joint economic lot size model for purchaser and vendor: a comment & & .894 & & & & & \\
\hline $\begin{array}{l}\text { The single vendor single buyer integrated production inventory model with a } \\
\text { generalised policy }\end{array}$ & & .890 & & & & & \\
\hline A one vendor multi buyer integrated inventory model: a comment & & .884 & & & & & \\
\hline Coordinated supply chain management & & .868 & & & & & \\
\hline A one vendor multi buyer integrated inventory model & & .865 & & & & & \\
\hline An integrated inventory model for a single supplier single customer problem & & .860 & & & & & \\
\hline Integrated inventory models: the buyer-vendor coordination & & .838 & & & & & \\
\hline A joint economic lot size model for purchaser and vendor & & .774 & & & & & \\
\hline $\begin{array}{l}\text { Stock replenishment and shipment scheduling for vendor managed inventory } \\
\text { systems }\end{array}$ & & .623 & & & & & \\
\hline An approach for developing an optimal discount pricing policy & & & .897 & & & & \\
\hline Coordinating a three level supply chain with quantity discounts & & & .815 & & & & \\
\hline A quantity discount pricing model to increase vendor profits & & & .814 & & & & \\
\hline Coordinating supply chain inventories through common replenishment epochs & & & .780 & & & & \\
\hline $\begin{array}{l}\text { Coordination mechanisms for a distribution system with one supplier and } \\
\text { multiple retailers }\end{array}$ & & & .745 & & & & \\
\hline A generalized quantity discount pricing model to increase supplier's profits & & & .741 & & & & \\
\hline Supply chain coordination with quantity discount policy & & & .734 & & & & \\
\hline Managing channel profits: comment & & & .697 & & & & \\
\hline Managing channel profits & & & .689 & & & & \\
\hline Channel coordination and quantity discounts & .522 & & .614 & & & & \\
\hline The Economic Institutions of Capitalism & & & & .843 & & & \\
\hline Arcs of integration: An international study of supply chain strategies & & & & .806 & & & \\
\hline Psychometric Theory & & & & .701 & & & \\
\hline \multicolumn{8}{|l|}{ Multivariate Data Analysis } \\
\hline \multicolumn{8}{|l|}{ The value of information sharing in a two level supply chain } \\
\hline Industrial Dynamics & & & & & .873 & & \\
\hline Supply Chain Management: Strategy, Planning and Operation & & & & & .721 & & \\
\hline The bullwhip effect in supply chains & & & & & & .796 & \\
\hline \multicolumn{8}{|l|}{ Information distortion in a supply chain: the bullwhip effect } \\
\hline Supply chain inventory management and the value of shared information & & & & & & & \\
\hline
\end{tabular}

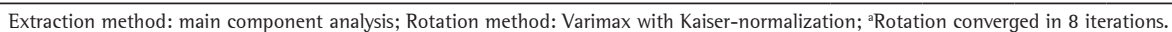

